personality. The most important tasks of aesthetic education are singled out. Aesthetic education is focused on the formation of aesthetic consciousness and aesthetic behavior of the individual. The formation of true aesthetic and spiritual values of student youth is impossible without a deep awareness of the national foundations of culture. One of the strongest factors of spontaneous aesthetic influence in the system of aesthetic education is nature. The effectiveness of aesthetic education of students largely depends on the skillful use by teachers of various ways and means. Aesthetic education of student youth involves a qualitative change in the level of their aesthetic culture.

Formation of true aesthetic and spiritual values of student youth is impossible without a deep awareness of the national foundations of culture, including folk songs, works of Ukrainian classical composers. Extremely important is a holistic approach to their assimilation of national culture: the study of history, mastering the aesthetic richness of language, attention to the beauty of the native land. One of the strongest factors of spontaneous aesthetic influence in the system of aesthetic education is nature. This influence is amplified provided that it is organized and managed by the teacher.

Aesthetic education of students is carried out by interpersonal influence between students, students and teachers in the educational process and in extracurricular activities. Aesthetic communication, which includes basic aesthetic skills of behavior, the aesthetics of human relationships at work, life, leisure, with a skillful organization has a powerful educational force.

Key words: aesthetic education, youth, culture, education, spiritual values.

\title{
UDC 378.018.54.091.2:784.071.2](510)(043.3)
}

Iryna Chystiakova

Sumy State Pedagogical University named after A.S. M akarenko ORCID ID 0000-0001-8645-510X

Zhang Lianhong

Sumy State Pedagogical University named after A.S. Makarenko ORCID ID 0000-0002-7416-3705

DOI 10.24139/2312-5993/2020.10/031-040

\section{WAYS OF VOCALISTS' PROFESSIONAL TRAINING IM PROVEMENT IN THE SYSTEM OF HIGHER MUSIC EDUCATION OF CHINA}

The article identifies the ways to improve the system of vocal training in higher music education institutions of China. The problems of professional vocal education in China are identified and characterized. The ways of solving the mentioned problems in the context of professional training of vocalists in the system of higher music education of China are offered: 1 ) to optimize professional vocal education management; 2 ) to create a national model of professional vocal education; 3 ) to optimally correlate quality and quantity in the process of vocalists' professional training; 4) to overcome isolation; 5) to train highly qualified teaching staff for institutions of higher music education; 6) to modernize the content of education in the process of professional training of vocal art specialists in the system of higher music education; 7) to intensify development and implementation of the methods of teaching vocalists, which would correspond to the new theoretical and methodological foundations of vocalists' professional training; 8) to develop a new working mechanism for graduates employment; 9) to limit the commercialization of education; 10) to develop a new educational model that takes into 
account the world experience of vocal training; 11 ) to systematically increase the level of pedagogical, scientific and performing personnel.

Key words improvement, professional training, vocalists, higher music education, China.

Introduction. Nowadays of particular importance have become the issues related to improving the university training of future musicians, including vocalists, by updating the content and introducing new core disciplines and electives, sections and topics of curricula, changing the format of teaching.

The urgency of this problem is due to the need to resolve a number of contradictions, namely between: the need for scientifically grounded conclusions about the essence of socio-cultural and pedagogical features of vocal art specialists training in the system of higher music education in China and the lack in modern Chinese studies of systematic analysis of this process, which allows to identify these features; the need to build the process of training vocal art specialists in the system of higher music education on a modern theoretical and methodological basis and the lack of scientific knowledge about the conceptual philosophical and pedagogical ideas underlying this process in the studied country; the need to identify the content and methods of training vocal art specialists that meet national cultural and educational characteristics, and the lack of research that solves this problem from the standpoint of a systematic approach to the system of higher music education in China.

Analysis of relevant research. The theory and practice of education have accumulated significant experience, which outlines promising areas of training for music professionals. In their scientific works, such representatives of China as Gao Huiwen, Cao Yanli, Zhang Wei, Zhao Xi, Yang Jing, etc., sought to clarify the peculiarities of the development of music education in China at the present stage of its reforming.

The aim of the article is to identify the ways to improve the system of vocal training in higher music education institutions in China.

Research methods. To solve this goal, a set of interrelated research methods was used: general scientific - analysis, synthesis, abstraction, comparison and generalization, which have allowed to clarify the features of theoretical approaches underlying development of the studied educational phenomenon, and to formulate the starting points and generalized conclusions of the study; specific-scientific - the method of terminological analysis provided the disclosure of the essence of the studied phenomena by identifying and clarifying the meanings of the basic concepts; the method of scientific extrapolation has made it possible to identify the prognostic potential of the interaction of vocal training systems in higher music education institutions in China. 
Research results. In order to identify the prognostic potential of vocal training systems in higher music education institutions in China, we consider it necessary to address the problems that exist in the system of vocalists' professional training in the country under investigation.

First of all, it should be noted that in China at the present stage there are processes of transformation, reform and modernization of vocal education.

Thus, the analysis of the professional education system in China has made it possible to identify such problems as:

1. The problem of managing professional vocal education.

2. The problem of creating a national model of professional vocal education.

3. The problem of overcoming isolation.

4. The problem of the ratio of quality and quantity in training of vocal art specialists.

5. The problem of training highly qualified teachers.

6. The problem of employment.

7. Negative experience of the introduction of the Bologna system.

Let's describe each of the identified problems.

1. The problem of managing professional vocal education. In China, the education model is based on the concept of centralized management of the music education system, i.e. it provides for administrative management of education institutions and the content of academic disciplines, as well as constant quality control of professional equipment used and centralized student counseling.

Thus, Chinese researchers emphasize the shortcoming of this model, namely the imbalance between the practical needs of the education institutions and the lack of professional music training in those who control the system (Yao Wei, 2010). Thus, in music education there is a shortage of professional thought.

It should be noted that the Chinese government controls education in all its spheres, but for the most part, education officials do not have vocal knowledge and do not understand real problems of music schools. This situation undoubtedly affects the quality of education and, accordingly, hinders its development. For example, the government often requires an increase in the number of students in order to improve attendance, while higher education institutions must take into account market demand, employment, adequacy of teachers and other organizational and methodological issues in the process of training future specialists. As a result, the problem of noncompliance of government requirements with the real situation is of growing concern to the teaching staff of music higher education institutions. 
2. The problem of creating a national model of vocal professional education. In the 21st century, the economy has united the world, modern globalization is developing a pluralism of cultures, and national cultures are enriching each other in the process of interaction. Vocal professional education as one of the musical phenomena should spread and promote the Chinese national culture. In China, each province has its own musical traditions, the study of which is necessary to form a specialist who is well acquainted with the best achievements of the musical culture of his country and understands the soul of his people.

In line with this idea, Wang Pingxu, a professor at the Shanghai State Conservatory, developed her own method of teaching vocals based on students' native dialects. This technique is relevant and innovative for Chinese vocal education, as the official language of China is "Putonghua" - the language of official communication and education, while the language of personal communication, the language of attachment to native culture for every Chinese is a dialect of his native place, which sometimes significantly differs from the state version.

3. The problem of overcoming isolation. It is believed that the most important direction in European vocals was and is academic singing, which originated in Italy, later various singers spread it around the world and improved. However, in modern society, new melodies appear, musical styles change, new musical genres emerge. Thus, a new concept is increasingly common in the scientific literature - "mixed singers". Such singers combine different styles, genres, vocal techniques during the performance of vocal works, rebuilding them and breaking stereotypes. Note that this innovation has received widespread public recognition. In addition, vocal professional education is gradually developing new forms of performance based on academic singing and adding modern musical elements (for example, a musical that not only combines academic and pop singing, but also jazz and blues).

In modern China, there are also singers, such as Tan Jing, who successfully combine academic, folk and pop singing. However, there are still very few such performers, which is due to the practical lack of appropriate directions and methods in the training of vocal art specialists.

It should be noted that a number of Chinese teachers have long begun a pedagogical search in this direction. For example, the famous vocal educator Jin Telin combines academic and folk singing, thanks to which his students demonstrate high results (Zhao Fuping, 2005).

4. The problem of the ratio of quality and quantity in the vocal art specialists' training. From the end of the twentieth century in China began to increase students' enrollment in all specialties of higher education. This 
phenomenon has strongly influenced not only professional education, but also Chinese society itself. As a result, full higher education has become more accessible in China. Consequently, we can observe a departure from the elite in higher education and transition to massification.

Vocal professional education has also undergone significant reforms. In the course of higher education reforms, vocal specialties have reached a high level, they are in demand and prosperous. At the same time, problems with the quality of education quickly emerged. Many students enter music higher education institutions every year, but there is a shortage of classrooms, dormitories, professional equipment and teaching staff. Thus, the problem of declining quality in education requires a thoughtful and comprehensive solution.

Another aspect of this problem is the contradiction between the predominant academic direction of vocal training in the system of higher music education and the aesthetic preferences of the audience, for which concerts and other vocal performances are organized (predominance of folk and pop directions in vocal art).

5. The problem of training highly qualified teachers. It is a well-known fact that the level of education of students depends on the professional competence of the teacher. According to Chinese researcher Zhang Wei, "in 1998, there were about 410,000 teachers in higher education sphere in China. And in 2010 the figure rose to 1,300,000" (Zhang Wei, 2005, p. 113). But at the same time, the number of students is growing much faster.

Teachers of the new generation are characterized by high educational qualifications, new knowledge and a strong theoretical background. However, it should be noted that they usually have little performance and pedagogical experience, as well as a very narrow specialization, which in practice means very little efficiency.

6. The problem of employment. From 1980 to 1990, there was a shortage of teachers in China due to unfavorable living conditions. Since 1999, China has expanded its admission to higher education institutions. As a result, there are almost no budget places in higher education institutions. Thus, at the same time there was a problem of graduates' employment. Tuition is paid, so higher education institutions are willing to recruit all interested applicants, regardless of the actual availability or absence of potential vacancies for graduates.

Note that the employment system in China has been constantly changing since 1949. Its development had two stages: the first stage lasted from 1949 to 1985, when the state distributed graduates to available vacancies, and the 
graduates were required to adhere to the distribution. The second stage, which began in 1985 and continues to present, has three employment scenarios.

The first scenario concerns students studying on a state budget basis, they choose a job under state management, with the HEl recommending the job, and the employer selects the best of the proposed candidates.

The second scenario is implemented in the case of a contractual form of training - the employer instructs the HEl to train the employees it needs, and graduates must return to the primary institution under contract.

The third scenario concerns commercial students who study with full reimbursement of tuition costs, such graduates can find a job on their own or on the recommendation of the $\mathrm{HEl}$ after graduating from a higher education institution.

In China, students usually do not work, all financial problems are solved by their parents. Only students from poor families earn their living, but they are few. After graduating from the higher education institution, Chinese students face the problem of choosing to be a singer or a singing teacher. These professions in China are well paid. The most popular specialty due to the lack of staff is now considered to be "Teacher of Academic Singing". In China, the work of teachers, educators and mentors has always been respected, and even now teachers are respected no less than government officials.

7. Negative experience of the introduction of the Bologna system. For example, undergraduate students in the 4th year have almost no classes. Their main task is to write a final qualifying work and find their own job. That is, students study for a bachelor's degree for almost 3 years. When it comes time for bachelors to take the exams to enter the master's program, they face a huge problem. In China, it is very important to pass an exam for knowledge of English, as well as knowledge of politics, and then a specialty. Then, after passing all the exams, you need to write a master's thesis.

Note that Chinese undergraduates usually spend a lot of time learning English, because it is a serious exam. In addition, China's master's degree focuses mainly on science rather than improving practical skills. Vocal creativity, which is a special subject for the vocalist, is thus a peripheral object of study of the undergraduate. As a result, the graduate of $\mathrm{HEl}$ is a versatile citizen, but not a very good vocalist-performer, because he did not have time to play music. Therefore, not all students receive diplomas (Zhao Xi, 2009). Almost all of them do not receive a diploma due to a failed English exam. This indicates, inter alia, a decrease in the requirements for professional knowledge and skills of undergraduates.

Note also that Chinese students do not work during their studies, while, for example, Ukrainian students combine work and study. Many vocalists in the 4th 
or 5th year are already working in the theater, mostly in the choir. This, on the one hand, testifies to the students' material and financial problems, but at the same time provides them with a solid professional practice. And in vocals, vocal skills are more important than a diploma, and even more than academic degrees.

It should be noted that there are too many bachelors in China today, and their professional level is not valued. This is a consequence of the 30-year spread of the Bologna system, the main purpose of which is research and obtaining scientific degrees, while art is a subtle sensory-emotional sphere that requires a fundamentally different approach to learning than science.

Therefore, the identified problems need to be addressed. In this study, we propose the following ways to solve these problems in the context of vocal training in the system of higher music education in China:

1. Optimize professional vocal education management. In our opinion, the solution to this problem can be active application of openness policy, including reliance on the experience of other countries. Chinese management representatives in the field of education, including vocal, would have the opportunity to obtain useful information and enrich knowledge through scientific exchange by inviting foreign teachers to give lectures and participate in the conferences. Such a practice would give new impetus to reforms in the vocal professional education system.

2. Create a national model of professional vocal education. Today in China, in the field of higher vocal professional education, the European model is mostly followed, Western vocal techniques and theories are copied in vocal education, ignoring the centuries-old experience of its people. In our opinion, it is possible to solve this problem based on the Chinese language and musical traditions, for which it will be expedient to introduce new vocal disciplines into the curriculum. This situation, in our opinion, can help students understand the special form of national vocals, master the native music and language systems, develop Chinese national vocal culture.

3. Optimally correlate quality and quantity in the process of vocal training. The problem of the ratio of quantity and quality in the training of vocal art specialists in the system of higher music education in China is related to the need to improve the quality of vocal education. Increasing the number of students, as well as the mechanical increase in the number of hours devoted to individual and practical classes, it seems to us, cannot lead to improved quality of vocal training in itself. This requires, in our opinion, implementation of the ideas of developmental learning, personality-centered education, which will identify and 
develop the abilities of each student, help students develop their own manner of performing vocal works, master traditional and modern vocal techniques.

Obviously, along with the academic direction in vocalists' training we should look, in our opinion, for teaching methods that will prepare vocalists who have a perfectly academic way of performing, various techniques of performing vocal works, but capable of variability, integration of elements of different styles, to performance of a fairly wide repertoire of vocal works. It should be noted that it does not mean adapting vocalists to the peculiarities of the so-called "mass culture" but taking into account the objective trends in the vocal art development in the process of their preparation.

4. Overcome isolation. In China, there is a need for diverse performers, respectively, the system of vocal education requires opening of the new branches that reflect the achievements of world music culture.

In addition, it is undeniable that the new era generates a rich and diverse musical culture, and therefore a good teacher should be able to combine musical traditions of different countries in vocal training and innovation, preparing students for different musical fields. An indispensable condition for such training is, of course, cultural exchange with the peoples of the world.

5. Train highly qualified personnel for teaching in institutions of higher music education. This problem can be solved by active participation in vocalperforming and scientific activities. In addition, improvement of the quality of professionalism in general can be achieved by creating a system that guarantees extracurricular activities for teachers, their participation in international conferences, exchanges between different institutions of higher education.

6. Modernize the content of education in the process of professional training of vocal art specialists in the system of higher music education.

7. Intensify development and implementation of the methods of teaching vocalists, which would correspond to the new theoretical and methodological foundations of vocalists' professional training. It is believed that modern Chinese vocalists do not have the necessary level of training, because, unlike European countries, China does not have the necessary training systems and methods. In this regard, an attempt is being made to systematize Western methods of teaching vocals, as well as to unite two cultures in practice.

8. Develop a new effective mechanism for graduates' employment. We are convinced that this problem should be in the center of attention not only of education institutions, but also of all teachers. In addition, art institutions of higher education should provide students with the necessary learning conditions in accordance with the requirements of the modern world. Improving the 
employment system of graduates, according to Yao Wei, is possible only with coordination of four components: control of the labor market and its simultaneous state regulation, recommendations of higher education institutions and mutual choice of graduates and employers (Yao Wei, 2010).

9. Limit education commercialization.

10. Develop a new educational model that takes into account the world experience of vocal training,

11. Systematically increase the level of pedagogical, scientific and performing staff.

Conclusions and prospects for further research. Thus, the reform of music organizations and the system of professional education must take into account changes in the culture and needs of modern society. Therefore, the state of vocal professional education will affect not only performers' training, but also inevitably affect the nature of society development. Vocal professional education should be open and serve to modernize China.

The issues of vocal training technologies in the system of higher music education in China deserve further study.

\section{REFERENCES}

Чжан, Вей (2005). Вокальна освіта в Китаї у XX століmmi. Сіань: Народна педагогіка (китайською мовою) (Zhang, Wei (2005). Vocal education in China in the XX century. Xian: Folk pedagogy (in Chinese)).

Чжао, Сі (2009). Про стан і розвиток вокальної освіти в Китаї. Велика сцена, 2, 68-69 (китайською мовою) (Zhao, Xi (2009). On the state and development of vocal education in China. Big Stage, 2, 68-69 (in Chinese)).

Чжао, Фупін (2005). Регіональна модель вокальної освіти в Китаї. Вісник Шаньсіського педагогічного університету, 3, 145-146 (китайською мовою) (Zhao, Fuping (2005). Regional model of vocal education in China. Bulletin of Shanxi Pedagogical University, 3, 145-146 (in Chinese)).

Яо, Вэй (2010). Проблемы вокального профессионального образования в Китае и России. Сборник материалов І Международной научно-практической конфреренции «Современная наука: теория и практика» Том второй (часть 2). Общественные науки. Ставрополь: СевКавГтУ, (сс. 405-408) (Yao, Wei (2010). Problems of vocal professional education in China and Russia. Proceedings of the I International Scientific and Practical Conference "Modern Science: Theory and Practice", Vol. Two (Part 2). Social sciences. Stavropol: SevKavGTU, (pp. 405-408)).

\section{PEЗЮME}

Чистякова Ирина, Чжан Лянхун. Пути усовершенствования профессионального образования вокалистов в системе высшего музыкального образования Китая.

В статье выявлены пути совершенствования системы профессиональной подготовки вокалистов в учреждениях высшего музыкального образования Китая. Определены и охарактеризованы проблемы профессионального вокального образования в Китае. Предложены пути решения указанных проблем в контексте профессиональной подготовки вокалистов в системе высшего музыкального образования Китая: 1)оптимизировать руководство профессиональным вокальным образованием; 
2) создать национальную модель профессионального вокального образования; 3) оптимально соотносить качество и количество в прочессе профрессиональной подготовки вокалистов; 4 п) преодолеть изоляцию; 5)готовить высококвалифицированные кадры для преподавания в учреждениях высшего музыкального образования; 6)модернизировать содержание обучения в процессе профессиональной подготовки специалистов вокального искусства в системе высшего музыкального образования; 7)активизировать разработку и внедрение методик обучения вокалистов, которые соответствовали бы новым теоретикометодологическим основам профессиональной подготовки вокалистов; 8) разработать новый работающий механизм трудоустройства выпускников; 9)ограничить коммерциализацию образования; 10)выработать новую образовательную модель, учитывающую мировой опыт вокальной подготовки; 11) планомерно повышать уровень педагогических, научных и исполнительских кадров.

Ключевые слова: совершенствование, профессиональная подготовка, вокалисты, высшее музыкальное образование, Китай.

\section{АНОТАЦІЯ}

Чистякова Ірина, Чжан Лянхун. Шляхи вдосконалення професійної підготовки вокалістів у системі вищої музичної освіти Китаю.

у статті виявлено шляхи вдосконалення системи професійної підготовки вокалістів у закладах вищої музичної освіти Китаю. Визначено та схарактеризовано проблеми професійної вокальної освіти в Китаї, як-от: 1)проблема управління професійною вокальною освітою. 2) проблема створення національної моделі професійної вокальної освіти. 3)проблема подолання ізолячії. 4)проблема співвідношення якості та кількості в підготовці фрахівців вокального мистецтва. 5) проблема підготовки висококвалірікованих педагогічних кадрів. 6) проблема працевлаштування. 7) негативний досвід введення Болонської системи.

Запропоновано шляхи вирішення означених проблем у контексті професійної підготовки вокалістів у системі вищої музичної освіти Китаю: 1) оптимізувати керівництво професійною вокальною освітою; 2) створити національну модель професійної вокальної освіти; 3) оптимально співвідносити якість і кількість у процесі продесійної підготовки вокалістів; 4)подолати ізоляцію; 5) готувати висококвалірікованих кадрів для викладання в закладах вищої музичної освіти; 6) модернізувати зміст навчання в процесі профресійної підготовки фрахівців вокального мистецтва в системі вищої музичної освіти; 7) активізувати розробку й упровадження методик навчання вокалістів, які відповідали би новим теоретико-методологічним основам професійної підготовки вокалістів; 8) розробити новий працюючий механізм працевлаштування випускників; 9) обмежити комерціалізацію освіти; 10) виробити нову освітню модель, що враховує світовий досвід вокальної підготовки; 11) планомірно підвищувати рівень педагогічних, наукових івиконавських кадрів.

Аргументовано, що реформа музичних організацій, системи професійної освіти має враховувати зміни в культурі й потребах сучасного суспільства. Констатовано, що те, якою буде вокальна професійна освіта, позначиться не тільки на підготовці виконавців, але й неминуче вплине на характер розвитку самого суспільства. Доведено, що вокальна професійна освіта повинна бути відкритою та служити модернізації Китаю.

Ключові слова: удосконалення, професійна підготовка, вокалісти, вища музична освіта, Китай. 